\title{
Isolated Head Injury Caused by Cathode Ray Tube Television Tip-over: Three Children Cases
}

\author{
Tüplü Televizyon Düşmesine Bağlı İole Kafa Travması: Üç Çocuk Olgu
}

\author{
(D) Gülşen Yalçın, (D) Murat Anıl, (D) Gamze Gökalp, (D) Emel Berksoy, (D) Sema Bozkaya Yılmaz, (D) Şule Demir \\ Tepecik Training And Research Hospital, Clinic of Pediatric Emergency Medicine, Izmir, Turkey
}

\section{Abstract}

Television tip-over injury is a home accident that can cause severe head trauma, especially in young children. In this study, three cases of television-related head trauma were presented. The first case was a 16-month-old girl. When she was playing at home, a cathode ray tube television rolled. A Skull fracture and intracranial injury developed. The children underwent emergency neurosurgery operation. He was hospitalized for 13 days and discharged. The second case was a 4-year-old male. He was found unconscious at home beside the overturned the cathode ray tube television. Subarachnoid hemorrhage was detected on tomography. He was hospitalized for 2 days and discharged. The third case was a 12-month-old boy. His mother accidentally dropped the cathode ray tube television on her child. Skull fracture and subgaleal hematoma were determined. In the follow-up, acute anemia developed and blood transfusion was performed in the emergency department. He was hospitalized for 2 days and discharged. In conclusion, television tip-over can lead to severe head trauma in children. Basic home preventive measures and adult supervision of young children may prevent television related-related injury.

Keywords: Television tip-over, home accident, head trauma, intracranial injury

\section{Öz}

Televizyon düşmesi, özellikle küçük çocuklarda ciddi kafa travmalarına neden olabilen bir ev kazasıdır. Bu çalışmada televizyon düşmesi sonucu kafa travması gelişen üç olgu sunuldu. Birinci olgu 16 aylık kız çocuktu. Evde oyun oynarken başına tüplü televizyon düştü. Kafatası kırığı ve kafa içi yaralanma gelişti. Acil ameliyata alındı. On üç gün hastanede yattı ve taburcu oldu. İkinci olgu 4 yaşında erkekti. Evde devrilmiş tüplü televizyonun yanında bilinçsiz halde bulundu.Tomografide subaraknoid kanama saptandı. Hastanede 48 saat izlendi ve taburcu oldu. Üçüncü olgu 12 aylık erkekti. Annesi yanlışlıkla tüplü televizyonu çocuğunun üzerine düşürdü. Kafatasında kırık ve subgaleal hematom saptandı. İzlemde akut anemi gelişti ve acil serviste kan transfüzyonu yapıldı. İki gün hastanede izlendi ve taburcu oldu. Sonuç olarak, televizyon düşmeleri çocuklarda ciddi kafa travmalarına yol açabilir. Basit ev içi koruyucu önlemler ve küçük çocukların erişkin gözetimi altında olması bu ev kazalarını önleyebilir.

Anahtar Kelimeler: Televizyon düşmesi, ev kazası, kafa travması, kafa içi yaralanma

\section{Introduction}

Home accidents are an important public health problem among children. ${ }^{1,2}$ The most common causes are lack of supervision and poor housing conditions. ${ }^{3}$ In our country, home accidents are the fourth leading cause of fatal child injury. ${ }^{4}$

Home accidents may result in serious physical injuries and permanent disabilities in children. In addition, psychological problems can arise in the child and his/her family. ${ }^{4}$ Television
(TV) is nowadays in every house. It has been reported that children watch TV more than 28 hours per week and the number of TV tip-over injuries increases accordingly. ${ }^{5}$ In a study conducted in our country, it was reported that in a 10-year period, 42 patients were admitted to emergency department because of the TV tip-over and $40.5 \%$ had head trauma. ${ }^{6}$

Here, we present 3 pediatric patients who were seriously injured due to cathode ray tube TV tip-over. We also aimed to draw attention to serious injuries caused by TV tip-over and the importance of taking precautions against it.

Address for Correspondence/Yazışma Adresi: Gülşen Yalçın, Tepecik Training And Research Hospital, Clinic Of Pediatric Emergency Medicine, İzmir, Turkey E-mail: drgyalcin@gmail.com ORCID ID: orcid.org/0000-0002-5938-2619 Received/Geliş Tarihi: 01.03.2018 Accepted/Kabul Tarihi: 16.02.2018 


\section{Case Report}

\section{Case 1}

A 16-month-old girl was brought to the emergency department by her family because of a cathode ray tube TV tip-over while playing at home. Her body temperature was $36.4{ }^{\circ} \mathrm{C}$, heart rate $-75 / \mathrm{min}$, respiratory rate - 26/ min, blood pressure - 152/99 mmHg, oxygen saturation $96 \%$, and Glasgow coma score (GCS) was 6 . There was no anisocoria and light reflex was present in both eyes. There were edema in the left parieto-occipital region, edema and echymosis in the right eye. The other physical examination findings were normal. The patient was given 100\% oxygen. Rapid sequence intubation was performed then mechanical ventilation was initiated. Intermittent bolus hypertonic saline $\left(3 \% \mathrm{NaCl}_{2}\right)$ was commenced for brain edema. Phenytoin prophylaxis was started. Blood glucose level was $257 \mathrm{mg} /$ $\mathrm{dL}$, however, other laboratory tests were within the normal limits. Occipital bone fracture and intracranial bleeding were detected on cranial computed tomography (CT) (Figure 1). External ventricular drainage was done in the operating room. After the operation, the child was followed up in the pediatric intensive care unit (PICU) for 6 days. She was exubated on the second day of PICU stay. Four day after operation, left central facial paralysis developed. Blepharitis in the right eye and retinal hemorrhage in the left retina were detected. The total length of hospital stay was thirteen days. She was discharged with left central facial paralysis.

\section{Case 2}

A four-year-old boy was brought to the pediatric emergency department after being found lying unconscious on the floor near a fallen cathode ray tube TV. The parents stated that he woke up on the way to the hospital. Vomiting and seizures were not described. Body temperature was $370 \mathrm{C}$, heart rate - 120/min, respiration - was 20/min and blood pressure was $112 / 74 \mathrm{mmHg}$. At the first examination in the emergency department, he was conscious, the pupils were equal in size, their response to light was normal, and GCS was 15 . No pathological findings were found on neurological examination. There was a small hematoma $(1 \times 1 \mathrm{~cm})$ in the left temporal region. The rest of the physical examination was normal. The complete blood count and basic blood biochemical tests were within the normal limits. Cerebral contusion was detected on cranial CT (Figure 2). The patient was discharged after 48 hours of uneventful follow-up at the neurosurgery ward.

\section{Case 3}

A 1-year-old boy was brought to the pediatric emergency department due to a home accident. In the story, the mother dropped the cathode ray TV to the child's head accidentally when she was pulling the table. His body temperature was $37.2^{\circ} \mathrm{C}$, heart rate $-127 /$ minute, respiration rate $-28 /$ minute, and blood pressure was $112 / 67 \mathrm{mmHg}$. Initial examination revealed normal state of consciousness, GCS of 15, normal light pupil test and equal pupils. Neurological examination was also normal. He had a hematoma $(1 \times 2 \mathrm{~cm})$ extending from the left frontal to occipital parts of the scalp. No pathological finding was found in the rest of the physical examination. A fracture was detected in occipital bone on cranial CT (Figure 3). Biochemical tests were normal. The first blood count showed microcytic anemia (hemoglobin=7.6 g/ $\mathrm{dL}$, hematocrit $=23.7 \%$, mean cell volume $(\mathrm{MCV})=57.8 \mathrm{fL}$, erythrocytes $=4100000 / \mathrm{mm}^{3}$ ). Hemoglobin and hematocrit levels and erythrocyte count decreased in the next two hours (hemoglobin=5.2 g/dL, hematocrit=16.4\%, MCV=58 fL, erythrocyte count $\left.=2840000 / \mathrm{mm}^{3}\right)$. Chest X-ray and abdominal
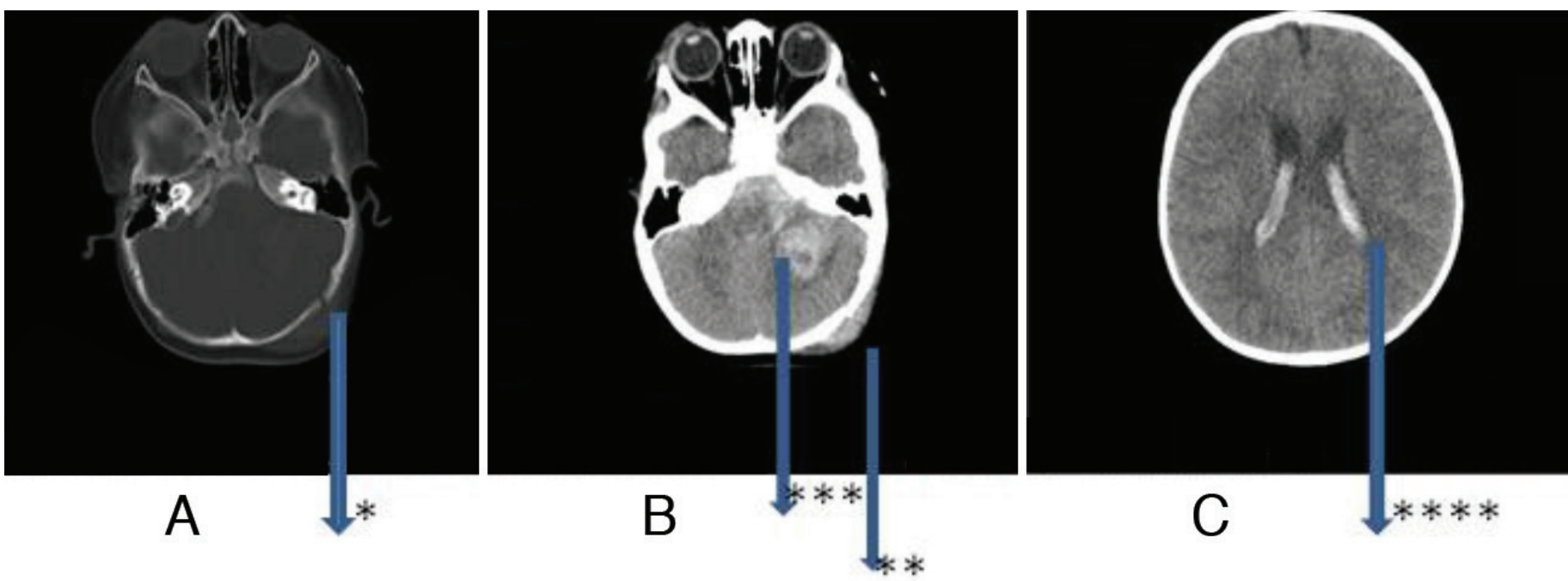

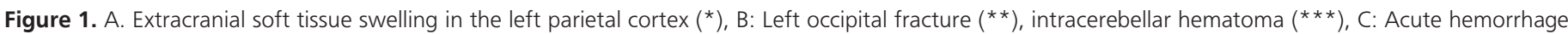

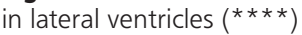




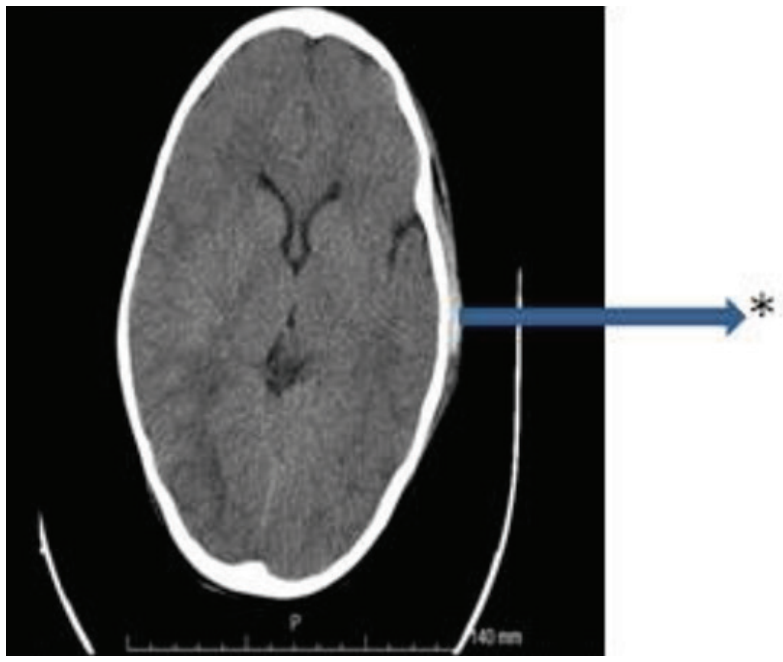

Figure 2. Subgaleal hemorrhage in left temporal, right parietal contusion $\left(^{*}\right)$

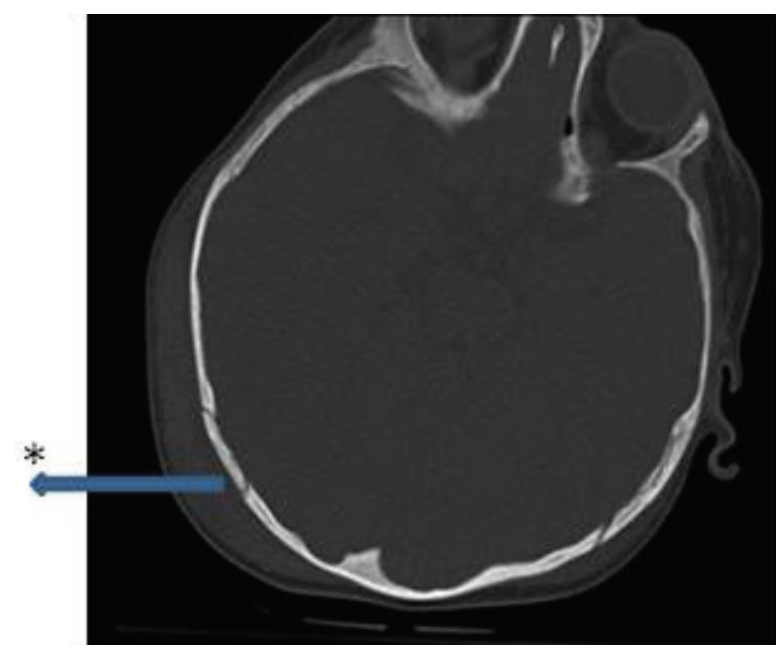

Figure 3. Right occipital fracture and subgaleal hematoma (*)

ultrasonography were normal. No further drop in hemoglobin level was noticed on follow-up. GCS was 15. The acute drop in hemoglobin and hematocrit levels and erythrocyte count was thought to be related to cephalic hematoma. Erythrocyte transfusion was done in the emergency department. He was discharged after 48 hours of follow-up at the neurosurgery ward.

\section{Discussion}

Injuries after TV tip-over in children were reported for the first time in 1998. ${ }^{7}$ Today, home accidents due to falling TV are a common public health problem seen all over the world and can cause serious head trauma. De Roo et al. ${ }^{8}$ reported that an estimated 380,885 patiens under 18 years of age were treated in emergency departments in the United States for an injury caused by TV falls between 1990 and 2011. The average annual injury rate was 2.43 injuries per 10.000 children. $^{8}$
In this paper, three children who were admitted to the pediatric emergency department due to TV tip-over were presented. These serious home accidents caused serious head injuries because appropriate precautions were not taken. Older model cathode ray tube TVs are heavier, unstable and prone to falling forward. ${ }^{9}$ Small children constitute the greatest risk group and the cases are often reported in the 1-3 year age range. ${ }^{10}$ Consistent with the literature, our patients were at the ages of 12 month, 16 month and 4 year. The sixteen-month-old boy, who was playing away from parental supervision, dropped the TV by himself. Case two was found unconscious near a fallen TV. Case three was injured by his parent unintentionally.

As a result, it seems that the injuries were caused by two reasons: lack of parental supervision and nonfixed cathode ray TV. The most serious injury due to TV falls is, as expected, intracranial injuries. ${ }^{11}$ In case of a TV tipping over on a small child, probably the first contact is occurred on the head and neck region. ${ }^{12}$ In a retrospective study conducted in Pakistan, a total of 22 children who had TV trolley tip-over injuries between 2009 and 2016 were included. It was found that 12 had skull bone fractures, 4 required neurosurgery, 1 developed a mild disability and one died in hospital. ${ }^{8}$ In a study from Turkey, among 53 cases injured due to TV tip-over, 8 patients had skull bone fractures. Three of them were followed in the PICU and one of them was lost. ${ }^{13}$ In the United States, a total of 218 patients who were injured due to a falling of TV between 2004 and 2006 were evaluated. Clinically significant injury was developed in 6 cases (death, brain surgery, intubation $>24$ hours, or hospitalization $>48$ hours). ${ }^{14}$ All cases in our study had head trauma. In the first case, skull fracture and intracranial hemorrhage were detected; emergency neurosurgery was performed. The patient was hospitalized 6 days in the PICU and seven days in the pediatric ward. The second case was followed up for 48 hours due to cerebral contusion in the neurosurgery ward. The third case needed blood transfusion due to scalp hemorrhage and was monitored in the hospital for two days.

In conclusion, home accidents caused by a falling TV can lead to serious injuries in young children. We should protect children from serious injuries, by taking some basic safety precautions such as preventing TV tipping, having infants and young children absolutely under adult supervision and being watchful especially when children are around. TV-related accidents can be preventable. TVs must be fixed properly.

\section{Ethics}

Informed Consent: A consent form was completed by all participants.

Peer-review: Externally and internally peer-reviewed. 


\section{Authorship Contributions}

Concept: G.Y., M.A., G.G., E.B., S.B.Y., Ş.D., Design: G.Y., M.A., G.G., E.B., S.B.Y., Ş.D., Data Collection or Processing: G.Y., M.A., G.G., E.B., S.B.Y., Ş.D., Analysis or Interpretation: G.Y., M.A., G.G., E.B., S.B.Y., S3.D., Literature Search: G.Y., M.A., G.G., E.B., S.B.Y., Ş.D., Writing: G.Y., M.A., G.G., E.B., S.B.Y., Ş.D.

Conflict of Interest: No conflict of interest was declared by the authors.

Financial Disclosure: The authors declared that this study received no financial support.

\section{References}

1. Schmertmann M, William SA, Black D. Stable age pattern supports role of development in unintentional childhood poisoning. Inj Prev. 2008;14:30-3.

2. Suresh N, Harini G, Radhika R, Chidambaram B. Head injuries in children resulting from the fall of television. Indian Journal of Pediatrics. 2010;77:459-60.

3. Turan T, Altundağ Dündar S, Yorgancı M, Yıldırım Z. 0-6 Yaş grubu çocuklarda ev kazalarının önlenmesi. Ulus Travma Acil Cerrahi Dergisi. 2010;16:552-7.

4. Altuntaş M, Kaya M, Demir Ş, Oyman G, Metecan A. ve ark. 0-14 Yaş arası çocuklarda önlenebilir nitelikteki kazaların belirlenmesi ve ilişkili tedbirlerin alınması. Smyrna Tıp Dergisi. 2013;1:28-33.

5. Muniz AE. Craniofacial injuries from television tip-over. Pediatric Emergency Care. 2012;28:52-4.
6. Guloğlu R, Sarıcı IS, Bademler S, Emirikçi S, İşsever H. et al. Falling television related child injuries in Turkey: 10-year experience. Turkish Journal of Trauma\&Emergency Surgey. 2012;18:61-4.

7. Bernard PA, Johnston C, Curtis SE, King WD. Toppled television sets cause significant pediatric morbidity and mortality. Pediatrics. 1998;102:32-5.

8. De Roo AC, Chounthırath T, Smith GA. Television-related injuries to children in the United States, 1990-2011. Pediatrics. 2013;132: 267-74.

9. Savku E, Atılla $H$, Yalçındağ FN. Çocukluk çağında televizyon düşmesi sonucu görülen göz problemleri. Türk Oftalmoloji Derg. 2013:43:451-4

10. Scheidler MG, Shultz BL, Schall L, Vyas A, Barksdale EM Jr. Falling televisions: The hidden danger for children. J Pediatr Surg. 2002;37:572-5

11. Yahya RR, Dirks P, Humphreys R, Rutka JT, Taylor M. et al. Children and television tip overs: A significant and preventable cause of long-term neurological deficits. Journal of Neurosurgery: Pediatrics. 2005; 103:219-22.

12. DiScala C, Barthel $M$, Sege R. Outcomes from television sets toppling onto toddlers. Archives of pediatrics\&adolescent medicine. 2001;155:145-8.

13. Bol O, Cebiçci H, Koyuncu S, Şarlı B, Günay N. A hidden household danger: Television. Ulus Travma Acil Cerrahi Derg. 2016;22:265-8.

14. Lichenstein R, Monroe D, Quayle KS, Miskin M, Cooper A. et al. Pediatric Emergency Care Applied Research Network (PECARN). Television-related head injuries in children: A Secondary analysis of a large cohort study of head-injured children in the pediatric emergency care applied research network. Pediatr Emerg Care. 2015 . 